\title{
Hubungan Lama Terapi Antipsikotik dengan Kadar SGOT dan SGPT pada Pasien Skizofrenia di RSJ Prof. H.B Sa'anin, Padang Tahun 2013
}

\author{
Cahyaningtyas $^{1}$, Rahmatini ${ }^{2}$, Kurniawan Sedjahtera $^{3}$
}

\begin{abstract}
Abstrak
Beberapa antipsikotik, diantaranya klorpromazin, haloperidol, dan risperidon, telah diselidiki dapat menyebabkan drugs-induced liver injury, berupa kolestasis dan kerusakan hepatoselular. Pemeriksaan SGOT/AST dan SGPT/ALT digunakan untuk skrining kerusakan hati. Tujuan penelitian ini adalah untuk mengetahui hubungan lama terapi antipsikotik dengan kadar SGOT dan SGPT. Telah dilakukan penelitian secara potong-lintang terhadap pasien skizofrenia rawat inap dengan terapi kombinasi klorpromazin, haloperidol, dan risperidon di RSJ Prof. H.B Sa'anin Padang periode 18-24 Desember 2013. Subyek penelitian dikelompokkan menjadi dua, yaitu pasien skizofrenia yang menerima terapi antipsikotik jangka pendek ( $\leq 6$ bulan) dan jangka panjang (> 6 bulan). Hasil pemeriksaan kadar SGOT dan SGPT antara dua kelompok dianalisis dengan menggunakan uji-t tidak berpasangan. Hasil penelitian pada 40 subyek penelitian dari total 143 pasien skizofrenia rawat inap menunjukkan rerata kadar SGOT dan SGPT pada kelompok terapi jangka pendek 22,6 $\pm 6,51 \mathrm{U} / \mathrm{l}$ dan 23,2 $\pm 12,16 \mathrm{U} / \mathrm{l}$, sedangkan kelompok terapi

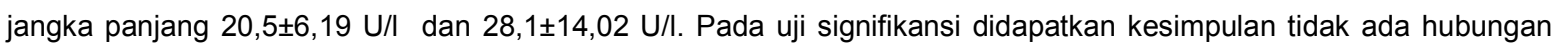
bermakna antara kadar SGOT dan SGPT dengan lama terapi antipsikotik jangka pendek dan panjang $(p>0,05)$.
\end{abstract}

Kata kunci: klorporomazin, haloperidol, risperidon, SGOT, SGPT

\begin{abstract}
Several antipsychotic drugs such as chlorpromazine, haloperidol, and risperidone, have been investigated to contribute on drugs-induced liver injury in form of cholestasis and hepatocelullar injury. SGOT/AST and SGPT/ALT tests were used to screen liver injury. The objective of this study was to analyse the correlation between duration of antipsychotics theraphy and SGOT/SGPT levels. A cross-sectional research was carried out in Prof. H.B Sa'anin Padang Mental Hospital upon schizophrenia in patient with chlorpromazine, haloperidol, and risperidone combination therapy within December, $18^{\text {th }}-24^{\text {th }}$ 2013. The study subjects were divided into two groups, patients with short-term $(\leq 6$ months) and long-term antipsyichotics theraphy (> 6 months). SGOT and SGPT level were observed. The mean level of SGOT and SGPT on both groups were analysed by independent $t$-test. Fourty study subjects were determined from total amount of schizophrenia patients. Results showed SGOT and SGPT mean level of short-term theraphy group $22,6 \pm 6,51 \mathrm{U} / \mathrm{I}$ and $23,2 \pm 12,16 \mathrm{U} / \mathrm{I}$ and in long-term theraphy group 20,5 $\pm 6,19 \mathrm{U} / \mathrm{I}$ and 28,1 $\pm 14,02 \mathrm{U} / \mathrm{l}$. There was no statistically significant correlation between SGOT/SGPT level with short-term and long-term antipsychotics therapy $(p>0,05)$.
\end{abstract}

Keywords: chlorpromazine, haloperidol, risperidone, SGOT, SGPT

Affiliasi penulis: 1. Prodi Profesi Dokter FK Unand (Faklutas Kedokteran Universitas Andalas Padang), 2. Bagian Farmakologi FK Unand, 3. Bagian Psikiatri FK Unand.

Korespondensi: Cahyaningtyas,Email: cahyaningtyas92@gmail.com Telp: 082124922073

\section{PENDAHULUAN}

Menurut buku DSM IV dan PPDGJ-III/ICD-X, skizofrenia adalah suatu sindrom psikopatologis yang biasanya ditandai oleh penyimpangan pikiran dan 
persepsi yang bersifat fundamental dan karakteristik disertai afek yang tidak wajar atau tumpul dengan kesadaran yang jernih dan kemampuan intelektual yang masih terjaga walaupun terkadang dapat terjadi kemunduran fungsi kognitif tertentu. ${ }^{1}$

Skizofrenia merupakan gangguan psikotik yang paling sering terjadi dimana hampir $1 \%$ penduduk dunia menderita skizofrenia selama hidupnya. ${ }^{2}$ Sumatera Barat menempati prevalensi tertinggi ketiga yaitu mencapai $1,6 \%$. Kasus gangguan jiwa di kota Padang yang menempati posisi teratas adalah psikotik (4.288 kasus). ${ }^{3}$ Berdasarkan studi pendahuluan pada data rekam medik RSJ Prof. H.B. Sa'anin Padang didapatkan data diagnosis terbanyak pasien rawat inap selama tahun 2012 adalah skizofrenia dan psikotik akut sebanyak 953 orang.

Penyebab skizofrenia masih belum dapat dimengerti. Studi riset menyatakan bahwa adanya peran faktor biologis, psikologi dan sosial. Faktor biologis yaitu hipotesis biokimia dan patologi otak serta identifikasi gen yang terlibat. Hipotesis biokimia terfokus pada hipotesis dopamin dan hipotesis serotonin. ${ }^{4}$

Penggunaan antipsikotik untuk mengatasi episode psikotik akut serta sebagai terapi rumatan untuk mencegah kekambuhan. Antipsikotik dapat berupa monoterapi maupun kombinasi. ${ }^{5}$ Pada rekam medic didapatkan umumnya pasien skizofrenia rawat inap di RSJ Prof. H.B. Sa'anin, Padang diterapi antipsikotik kombinasi dalam jangka waktu relatif lama, antipsikotik yang umumnya digunakan adalah klorpromazin dan haloperidol.

Sebagian besar antipsikotik harus melewati proses metabolisme lengkap di hati agar dapat diekskresi melalui ginjal, oleh karena itu kemungkinan besar antipsikotik dapat menyebabkan jejas hati diinduksi obat (Drugs-Induced Liver Injury/DILI). ${ }^{6}$ Enzim transaminase yaitu SGOT/AST (serum glutamic oxaloacetic transaminase/aspartate transaminase) dan SGPT/ALT (serum glutamic pyruvic transaminase/ alanine transaminase) dapat digunakan sebagai skrining ataupun pemeriksaan kerusakan sel-sel hati (hepatocellular injury) yang disebabkan oleh berbagai etiologi termasuk DILI. ${ }^{7}$ Dari hasil beberapa penelitian, jejas hati diinduksi antipsikotik biasanya berupa peningkatan sementara enzim transaminase, asimtomatik, tidak tergantung dosis, dan waktu yang dibutuhkan untuk terjadi peningkatan bervariasi serta peningkatan bersifat reversibel jika segera dihentikan maupun dilanjutkan penggunaan obat-obatan tersebut. ${ }^{8,9}$

Penelitian ini dilakukan untuk mengetahui hubungan lama terapi antipsikotik jangka pendek dan jangka panjang dengan kadar SGOT dan SGPT pada pasien skizofrenia di RSJ Prof. H.B. Sa'anin, Padang.

\section{METODE}

Penelitian ini telah dilakukan di lima bangsal RSJ Prof. H.B Sa'anin, Padang periode 18-24 Desember 2013 pada 143 orang pasien skizofrenia rawat inap kelas III. Berdasarkan rumus uji beda rerata dua kelompok tidak berpasangan, diambil sampel sebanyak 40 orang untuk dua kelompok terapi jangka pendek ( $\leq 6$ bulan) dan terapi jangka panjang $(>6$ bulan); menggunakan kombinasi dua antipsikotik CPZ, haloperidol, dan risperidon dan tidak putus obat minimal 2 minggu; tidak sedang/memiliki riwayat kelainan hati, kelainan kardiovaskular, dan/atau konsumsi alkohol; serta tidak mengkonsumsi obatobatan lain yang dapat menimbulkan DILI.

Penelitian ini bersifat analitik dengan desain cross sectional. Pengolahan data dilakukan dengan uji-t tidak berpasangan secara komputerisasi. Variabel independen adalah lama terapi antipsikotik dan dependen adalah kadar SGOT dan SGPT.

\section{HASIL}

Tabel 1. Karakteristik subyek penelitian

\begin{tabular}{lc}
\hline \multicolumn{1}{c}{ Karakteristik } & Nilai Statistik \\
\hline $\begin{array}{l}\text { Jumlah Sampel } \\
\text { Jenis Kelamin }\end{array}$ & 40 orang \\
$\quad$ Laki-laki $(\mathrm{n}, \%)$ & 33 orang $(82,5 \%)$ \\
$\quad$ Perempuan $(\mathrm{n}, \%)$ & 7 orang $(17,5 \%)$ \\
Usia (tahun) & \\
$<20$ tahun & 1 orang $(2,5 \%)$ \\
$20-40$ tahun & 24 orang $(60 \%)$ \\
$>40$ tahun & 15 orang $(37,5 \%)$ \\
Rata-rata usia (mean \pm SD) & $37 \pm 8,45$ \\
\hline
\end{tabular}


Berdasarkan Tabel 1 dapat dilihat bahwa sebagian besar subyek penelitian ini adalah laki-laki, sebanyak 33 orang $(82,5 \%)$ dan perempuan 7 orang $(17,5 \%)$. Frekuensi usia pasien skizofrenia terbanyak adalah kelompok usia 20-40 tahun sebanyak 24 orang $(60 \%)$.

Tabel 2. Regimen terapi antipsikotik subyek penelitian

\begin{tabular}{ccc}
\hline \multirow{2}{*}{$\begin{array}{c}\text { Regimen } \\
\text { Terapi }\end{array}$} & \multicolumn{2}{c}{ Frekuensi } \\
\cline { 2 - 3 } & Jangka Pendek & Jangka Panjang \\
(n) & (n) \\
\hline CPZ dan HLP & 7 & 7 \\
CPZ dan RISP & 11 & 9 \\
HLP dan RISP & 2 & 4 \\
\hline Jumlah & 20 & 20
\end{tabular}

CPZ=klorpromazin, $\mathrm{HLP}=$ haloperidol, $\mathrm{RISP}=$ risperidon

Berdasarkan Tabel 2 dapat dilihat bahwa regimen terapi antipsikotik yang digunakan oleh subyek penelitian terbanyak pada kedua kelompok adalah kombinasi klorpromazin-risperidon yaitu sebanyak 11 orang dan 9 orang.

Tabel 3. Lama terapi antipsikotik kombinasi

\begin{tabular}{ccc}
\hline \multirow{2}{*}{ Lama Terapi Antipsikotik } & \multicolumn{2}{c}{ Frekuensi } \\
\cline { 2 - 3 } & $\mathbf{n}$ & $\%$ \\
\hline Jangka Pendek & 20 & 50 \\
Jangka Panjang & 20 & 50 \\
\hline Jumlah & 40 & 100 \\
\hline
\end{tabular}

Berdasarkan Tabel 3 dapat diketahui bahwa, dari dua kelompok terapi, jumlah subyek yang mendapatkan terapi antipsikotik jangka pendek dan jangka panjang adalah sama yaitu masing-masing 20 orang $(50 \%)$.

Tabel 4. Kategori kadar SGOT dan SGPT kelompok terapi jangka pendek

\begin{tabular}{ccc}
\hline Enzim & $\mathbf{f}$ & $\mathbf{n ~ ( \% )}$ \\
Transaminase & & \\
\hline \multirow{2}{*}{ Kadar SGOT } & Normal & $19(97,5 \%)$ \\
& Abnormal & $1(2,5 \%)$ \\
Kadar SGPT & Normal & $18(95 \%)$ \\
& Abnormal & $2(5 \%)$ \\
\hline Jumlah & & $40(100 \%)$ \\
\hline
\end{tabular}

Berdasarkan Tabel 4 dapat diketahui bahwa, pada kelompok terapi jangka pendek terdapat 1 orang yang memiliki kadar SGOT abnormal sebesar 41,2 U/I. Subyek penelitian yang memiliki kadar SGPT abnormal sebanyak 2 orang, yaitu sebesar $44 \mathrm{U} / \mathrm{I}$ dan $59 \mathrm{U} / \mathrm{l}$.

Tabel 5. Kategori kadar SGOT dan SGPT kelompok terapi jangka panjang

\begin{tabular}{ccc}
\hline $\begin{array}{c}\text { Enzim } \\
\text { Transaminase }\end{array}$ & $\mathbf{f}$ & $\mathbf{n ~ ( \% )}$ \\
\hline Kadar SGOT & Normal & $20(100 \%)$ \\
& Abnormal & - \\
Kadar SGPT & Normal & $15(75 \%)$ \\
& Abnormal & $5(25 \%)$ \\
\hline Jumlah & & $40(100 \%)$ \\
\hline
\end{tabular}

Berdasarkan Tabel 5 dapat diketahui bahwa, kadar SGOT pada subyek penelitian kelompok terapi jangka panjang seluruhnya dalam batas normal. Sedangkan terdapat 5 orang yang memiliki kadar SGPT abnormal, kadar SGPT tertinggi pada kelompok ini sebesar $63 \mathrm{U} / \mathrm{l}$.

Tabel 6. Nilai kadar SGOT berdasarkan lama terapi antipsikotik kombinasi

\begin{tabular}{cccccc}
\hline SGOT & $\begin{array}{c}\mathbf{n} \\
(\%)\end{array}$ & $\begin{array}{c}\text { mean (U/I) } \pm \\
\text { SD }\end{array}$ & $\begin{array}{c}\text { Min } \\
(\mathrm{U} / \mathrm{l})\end{array}$ & $\begin{array}{c}\text { Maks } \\
(\mathrm{U} / \mathrm{l})\end{array}$ & $\mathbf{P}$ \\
\hline $\begin{array}{c}\text { Jangka } \\
\text { Pendek }\end{array}$ & 20 & $22,6 \pm 6,5$ & 11 & 41,2 & \\
$\begin{array}{l}\text { Jangka } \\
\text { Panjang }\end{array}$ & 20 & $20,5 \pm 6,19$ & 10 & 31,4 & 0,607 \\
\hline
\end{tabular}

Berdasarkan Tabel 6 dapat dilihat bahwa $p$-value dari kadar SGOT berdasarkan lama terapi antipsikotikkombinasi jangka pendek dan jangka panjang adalah 0,607

Tabel 7. Nilai kadar SGPT berdasarkan lama terapi antipsikotik kombinasi

\begin{tabular}{cccccc}
\hline SGPT & $\begin{array}{c}\mathbf{n} \\
(\%)\end{array}$ & $\begin{array}{c}\text { mean (U/I) } \pm \\
\text { SD }\end{array}$ & $\begin{array}{c}\text { Min } \\
(\mathbf{U} / \mathrm{l})\end{array}$ & $\begin{array}{c}\text { Maks } \\
(\mathrm{U} / \mathrm{l})\end{array}$ & $\mathbf{P}$ \\
\hline Jangka & 20 & & 8 & 59 & \\
$\begin{array}{l}\text { Pendek } \\
\text { Jangka } \\
\text { Panjang }\end{array}$ & 20 & $23,2 \pm 12,16$ & & & 0,448 \\
\hline
\end{tabular}


Kadar SGPT pada Tabel 7 adalah 0,448 (dimana nilai $\mathrm{p}$ yang dianggap bermakna adalah < $0,05)$ artinya tidak terdapat hubungan yang bermakna antara kadar SGOT maupun SGPT dengan lama terapi antipsikotik kombinasi dalam waktu jangka pendek maupun jangka panjang pada pasien skizofrenia di RSJ Prof. H.B Sa'anin, Padang.

\section{PEMBAHASAN}

Tabel 1 menunjukkan sebagian besar subyek penelitian adalah laki-laki. Rata-rata usia subyek penelitian adalah 37 tahun (rentang usia 20-40 tahun). Hasil ini sesuai dengan yang disebutkan oleh Sinaga yaitu prevalensi skizofrenia berdasarkan jenis kelamin, ras, dan budaya adalah sama, namun wanita cenderung mengalami gejala yang lebih ringan dan lebih sedikit rawat inap dibandingkan laki-laki. ${ }^{10}$ Pada penelitian ini jenis kelamin, usia, ras, dan subtipe skizofrenia subyek penelitian tidak diteliti pengaruhnya terhadap kadar SGOT dan SGPT.

Pada penelitian ini subyek penelitian yang dipilih untuk kedua kelompok adalah pasien skizofrenia di lima bangsal kelas III dengan terapi antipsikotik kombinasi klorpromazin-haloperidol, klorpromazin-risperidon, dan risperidon-haloperidol. Hal tersebut dilakukan karena sebagian besar pasien rawat inap di RSJ Prof. H.B Sa'anin, Padang diterapi dengan kombinasi antipsikotik. Hal tersebut sesuai dengan penelitian yang dilakukan oleh Craig dan Miller, dimana terjadi peningkatan penggunaan antipsikotik kombinasi walaupun belum ada bukti yang kuat mengenai manfaat dan keamanan kombinasi tersebut. Kombinasi yang tersering adalah sebuah antipsikotik tipikal, seperti klorpromazin dan haloperidol, dengan risperidon. ${ }^{11}$

Penggunaan obat multipel merupakan salah satu faktor kerentanan terjadinya kerusakan hati ${ }^{6,12}$ sehingga pada penelitian ini untuk menghindari bias, pada kedua kelompok dipilih subyek yang sama-sama menggunakan kombinasi dua antipsikotik. Antipsikotik yang dipilih adalah klorpromazin, haloperidol, dan risperidon yang secara teori dan dibuktikan oleh beberapa penelitian dapat menyebabkan hepatotoksisitas, salah satunya dari hasil penelitian ekspresi gen pada jaringan hati post mortem yang dilakukan Choi et al, antipsikotik tipikal dan tipikal (fenotiazin, haloperidol, olanzapin, dan risperidon) dapat menimbulkan efek samping hepatotoksisitas melalui berbagai mekanisme yang melibatkan ekspresi gen hepatosit tertentu. ${ }^{13}$

Pada Tabel 3 dapat dilihat bahwa masingmasing kelompok terapi antipsikotik jangka pendek ( $\leq$ 6 bulan) serta jangka panjang ( $>6$ bulan) berjumlah 20 orang. Pembagian kelompok terapi tersebut sesuai dengan kriteria inklusi dalam penelitian yang dilakukan oleh Erdogan et al mengenai lama penggunaan risperidon yang dapat berhubungan dengan abnormalitas tes yaitu minimal enam bulan sampai saat dilakukan penelitian. ${ }^{14}$

Pada Tabel 4 dan 5 dapat dilihat kategori kadar SGOT dan SGPT (normal/abnormal) pada kedua kelompok terapi jangka pendek dan jangka panjang. Namun peningkatan kadar SGOT dan SGPT ini tidak diketahui berhubungan atau tidak dengan penggunaan obat karena tidak dilakukan uji coba penghentian obat dibarengi dengan monitoring kadar enzim transaminasenya (rechallenge test).

Hasil tersebut berlawanan dengan teori dalam penelitian LInaire et al dan penelitian De Leon dan Spina mengenai salah satu adverse effect akibat terapi kombinasi adalah terjadi interaksi obat dalam proses metabolisme obat yang melibatkan enzim sitokrom P450 (CYP). Dimana klorpromazin merupakan inhibitor poten enzim CYP2D6, yang dapat mengganggu eliminasi antipsikotik lain yang tergantung pada enzim tersebut seperti risperidon. Klirens risperidon terganggu menyebabkan konsentrasinya meningkat dalam plasma dan pada pasien yang rentan mungkin dapat meningkatkan resiko jejas hati. ${ }^{15,16}$

Pada Tabel 6 dan 7 dapat dilihat bahwa secara statistik dengan menggunakani uji $t$ tidak berhubungan, tidak terdapat hubungan bermakna antara lama terapi antipsikotik-kombinasi jangka pendek ( $\leq 6$ bulan) dan jangka panjang ( $>6$ bulan) dengan kadar SGOT dan SGPT pada pasien skizofrennia di RSJ Prof. H.B. Sa'anin, Padang. Hal tersebut hampir sama dengan hasil penelitian Erdogan et al pada 102 subyek penelitian yang sengaja diterapi risperidon tunggal selama enambulan. Dalam studi 
penelitian kohort tersebut, salah satu parameter adalah nilai SGOT dan SGPT awal (baseline), satu bulan pertama dan enam bulan pertama pemberian risperidon. Secara statistik tidak didapatkan perubahan signifikan enzim-enzim hati dan bilirubin antara bulan pertama dan bulan keenam. Namun ada peningkatan bermakna ( $p=0,0001)$ kadar SGOT dan SGPT pada saat awal penelitian dengan setelah enam bulan. ${ }^{14}$

Penelitian mengenai efek penggunaan antipsikotik kombinasi terhadap hati berupa perubahan pada tes fungsi hati, masih sangat kurang. Penelitianpenelitian sebelumnya lebih banyak membahas tentang efek samping penggunaan kombinasi antipsikotik dengan obat golongan lain yang biasa dijadikan terapi tambahan pada kasus psikiatri, seperti kombinasi antipsikotik dengan golongan antiepilepsi, antidepresan, mood stabilizer, dan lain-lain.

Penelitian ini tidak mendapatkan hubungan bermakna antara lama terapi antipsikotik jangka pendek dan jangka panjang dengan kadar SGOT dan SGPT, hal tersebut mungkin disebabkan oleh keterbatasan jumlah subyek penelitian dan desain penelitian yang menggunakan desain cross-sectional. Peningkatan kadar SGOT dan SGPT akibat penggunaan antipsikotik tunggal maupun kombinasi sangat mungkin terjadi akibat reaksi idiosinkratik, namun sangat tergantung dari faktor individu. Pada penelitian ini tidak ada subyek penelitian yang mengalami peningkatan kadar SGOT dan SGPT yang bermakna klinis (menandakan jejas hati), kemungkinan karena kerusakan hepatik dapat menghilang walaupun penggunaan obat diteruskan atau dilakukan rechallenge. Hal tersebut karena adanya proses perubahan adaptif pada hepatosit yang melibatkan regulasi gen-gen antioksidan atau protein chaperone. $^{9}$

\section{KESIMPULAN}

Tidak terdapat hubungan bermakna antara lama terapi antipsikotik jangka pendek dan jangka panjang dengan kadar SGOT dan SGPT pada pasien skizofrenia di RSJ Prof. H.B sa'anin. Padang pada tahun 2013

\section{UCAPAN TERIMA KASIH}

Bersama ini kami juga turut mengucapkan terima kasih kepada Kepala Direktur, seluruh dokter dan staf, serta pasien RSJ Prof. H.B Sa'anin, Padang yang telah membantu dan mendukung penelitian ini.

\section{DAFTAR PUSTAKA}

1. Maslim R. Buku saku diagnosis gangguan jiwa rujukan ringkas dari PPDGJ-III. Edisi ke-1. Jakarta: Bagian IImu Kedokteran Jiwa FK-Unika Atmajaya; 2001.hlm.46.

2. Amir N. Skizofrenia. Dalam: Elvira SD, Hadisukanto G, editor (penyunting). Buku ajar psikiatri. Jakarta: Badan Penerbit FKUI; 2010. hlm. 170-8.

3. Dinas Kesehatan Kota Padang. Laporan tahunan tahun 2008 Edisi 2009. Padang: DKK; 2009. hlm. 60.

4. Maria JNA. Peran atypical antipsychotic dalam menurunkan perilaku agresif pada pasien skizofrenia. E-jurnal Medika Udayana. 2013; 2(2): 1-19.

5. Ganguly R. Antipsychotic polypharmacy vs. monotherapy in the treatment of schizophrenia (dissertation). Georgia: University of Georgia; 2003. hlm. 4-10.

6. Matfin G, Porth CM, Pathophysiology concepts of altered health states. Edisi ke-8. North America: Lippincott Williams \& Wilkins; 2009. hlm. 957-9.

7. Lee WM, 2003. Drug-induced hepatotoxicity. N Eng J Med. 2003;349(5):474-85.

8. Atasoy N, Atik L, Erdogan A, Konuk N, Ozturk U, Ustundag $\mathrm{Y}$, et al. A review of liver function tests during treatment with atypical antipsychotic drugs : a chart review study. NeuroPsychofarmakology \& Biology Psychiatri. 2007;(31):1255-60.

9. Marwick KFM, Taylor M, Walker SW. Antipsychotics and abnormal liver function tests : systematic review. Clin Neuropharm. 2012;35(5): 244-53.

10. Sinaga BR. Skizofrenia dan diagnosis banding. Jakarta: Badan Penerbit FKUI; 2007. hlm. 4, 12, 23, 35-9, 197. 
11. Craig CS, Miller AL. Combination antipsychotics : pros, cons, and questions. Schizophrenia Bulletin. 2002;28(1):105-9.

12. Goldman L, Schafer A. Goldman's Cecil Medicine. Edisi ke-24. Philadhelphia: Elseiver Saunders; 2012. hlm. 979-84.

13. Choi KH, Dulay J, Higgs BWL, Ida C, Song J, Yolken $\mathrm{RH}$, et al. Effects of typical and atypical antipsychotic drugs on gene expression profiles in the liver of schizophrenia subjects. BioMed Central Psychiatri. 2009;(9):57-62.

14. Erdogan A, Karaman MG, Kurcer MA, Ozdemir E, Tufan AE, Yurteri N. Six months of treatment with riperidone may be associated with nonsignificant abnormalities of liver function tests in children and adolescents: a longitudinal, observational study from Turkey. Journal of Child and Adolescent Psychopharmacology. 2010;(20):407-13.

15. Llinares F, Grana EC, Martinez EP, Ordovas JP, Prats $\mathrm{CH}$, Polo JN. Acute cholestatic hepatitis probably associated with risperidone. Int'I Psychiatry in Medicine. 2005;35(4):199-205.

16. De Leon J, Spina E. Metabolic drug interactions with newer antipsychotics: a comparative review. Basic \& Clinical Pharmacology \& Toxicology. 2007;(100):4-22. 